\title{
Prospects for new leprosy diagnostic tools, a narrative review considering ELISA and PCR assays
}

\author{
Rafael Silva Gama[1], Lázaro Azevedo Leite ${ }^{[1]}$, \\ Lívia Tavares Colombo ${ }^{[1]}$ and Lúcia Alves de Oliveira Fraga ${ }^{[2]}$
}

[1]. Universidade Vale do Rio Doce, Laboratório de Biologia Molecular, Governador Valadares, MG, Brasil. [2]. Universidade Federal de Juiz de Fora, Departamento de Ciências da Vida, Governador Valadares, MG, Brasil.

\begin{abstract}
Slit skin smear and histopathological examinations are currently the main laboratory tools used to aid the diagnosis of leprosy. However, their sensitivity is low, and many cases are not detected. New methodologies have been studied to develop more accurate tests. This narrative review aims to raise attention to the results of molecular (polymerase chain reaction) and serological (Enzyme-Linked Immunosorbent Assay) tests applied to the diagnosis of leprosy, and to summarize the available information about the former. Original scientific articles published in indexed international journals, whose study involved aspects of the diagnosis and classification of leprosy cases or home contacts, were selected. The data were extracted independently using a standardized method that dictated the inclusion of the following information: diagnosis in Paucibacillary and Multibacillary cases and in household contacts; sample number; sample type; study design; studied variables; statistical analysis employed; main results; and limitations identified. In clinical practice, the results from molecular and serological tests are assessed separately, with moderate sensitivity and specificity. However, an integrated study of these methodologies has been suggested for greater accuracy in diagnosis.
\end{abstract}

Keywords: Leprosy. Polymerase Chain Reaction. Serologic Tests.

\section{INTRODUCTION}

Leprosy is a chronic granulomatous infection that mainly affects the skin and peripheral nerves, presenting several clinical manifestations due to the pattern of the immune response established as a result of infection with Mycobacterium leprae ${ }^{1}$. The disease is considered a public health issue in countries where the annual prevalence rate is greater than 1 case per 10,000 inhabitants. It is endemic in several countries with low levels of social and economic development, especially India and Brazil, with the highest absolute number of cases in the former. In 2018, 208,619 new leprosy cases were registered worldwide by the World Health Organization (WHO). Preliminary data for 2019 show 120,334 and 26,612 new leprosy cases for India and Brazil, respectively, both classified as high-load countries ${ }^{2,3}$.

\footnotetext{
Corresponding author: Dr. Rafael Silva Gama

e-mail: rafael.gama@univale.br

(i) https://orcid.org/0000-0003-3035-7927

Received 20 July 2020

Accepted 26 October 2020
}

Transmission likely occurs via the upper respiratory airway through prolonged contact with untreated infected patients. Poor socioeconomic and sanitary conditions as well as genetic predisposition, seem to play an essential role in the development of the disease ${ }^{4,5}$.

Early detection of the disease is a strategy to stop the transmission of M. leprae and to prevent the occurrence of physical disability. However, leprosy is still mainly diagnosed based on clinical examination, and in many cases the symptoms are subtle and often not noticed by specialists. Slit skin smear and histopathological examinations are used to aid the clinical diagnosis and are useful in spectral and treatment categorization ${ }^{6}$. New methodologies have been studied for the development of more effective tests. Among these, molecular and serological assays such as polymerase chain reaction (PCR), Enzyme-Linked Immunosorbent Assay (ELISA), and rapid tests have stood out. This narrative review aims to raise awareness of the results of molecular and serological tests applied to the diagnosis of leprosy and to highlight key points about the former. 


\section{CURRENT DIAGNOSTIC ASSAYS}

The bacilloscopic exam evaluates the bacillary load and morphology. In Brazil, the Ministry of Health recommends performing a slit skin smear from four sites. The preferred sites are active lesions or lesions with altered sensitivity as well as the ear lobes and the contralateral elbow. In the absence of injury, intradermal shaving should be performed on both ear lobes and elbows ${ }^{7}$. The slit skin smear exam has a specificity close to $100 \%$; however, it has low sensitivity, since it is positive in only $30 \%$ of infected patients ${ }^{8}$. Patients with up to five skin lesions are considered paucibacillary (PB), and those with six or more lesions are classified as multibacillary (MB). A slit skin smear should be performed, if available, and a positive result classifies the case as MB. However, a negative result does not rule out the clinical diagnosis of leprosy and does not necessarily classify the patient as $\mathrm{PB}^{9}$.

Histopathological examination is often performed to confirm clinically dubious cases. Additionally, it is used as one of the criteria in the Ridley-Jopling spectral classification that defines five spectral types of leprosy. The predominant ones are the polar tuberculoid (TT) and the lepromatous (LL) forms. The TT form has a low bacillary load, high cellular immune response, and low antibody production, while the LL form has a high bacillary load, increased antibody production, and reduced cellular immune response. In addition to these, immunologically and clinically unstable forms are described, including borderline-tuberculoid (BT), borderlineborderline (BB), and borderline-lepromatous (BL) ${ }^{10}$. Early diagnosis of leprosy in subclinical infections could be essential for the rapid interruption of the disease transmission chain, and to prevent the development of leprosy sequelae by prompt treatment. Therefore, the establishment of a sensitive test for leprosy diagnosis has been a leading research objective ${ }^{11}$.

\section{MOLECULAR ASSAYS}

Unlike slit skin smears, which require about $10^{4}$ bacilli per gram of tissue for reliable detection, polymerase chain reaction (PCR) is a technique with high specificity and sensitivity, capable of detecting 25 $\mathrm{fg}\left(10^{-15} \mathrm{~g}\right)$ of deoxyribonucleic acid (DNA) from M. leprae. Moreover, the possibility of its use in almost all types of clinical samples gives this method a high potential for differential diagnosis ${ }^{12,13}$. Different sequences and target genes have been used for the amplification of M. leprae DNA, mostly from skin biopsies, by PCR. Specific and straightforward systems were used to amplify gene regions that encode the $M$. leprae $36-\mathrm{kDa}^{14,15}$ or $65-\mathrm{kDa}^{16}$ antigens, repetitive sequences (RLEP), and the 16S ribosomal RNA(rRNA) subunit ${ }^{17,18,19}$.

To develop a more sensitive and specific method for the molecular detection of M. leprae, was compared the PCR amplification of two regions, the $18-\mathrm{kDa}$ gene and the RLEP, which was more sensitive ${ }^{12}$. The relatively high number of copies of the RLEP sequence in the $M$. leprae genome, estimated to contain at least 28 copies, likely gives this target a greater sensitivity compared to single-copy genes ${ }^{17}$. Goulart and Goulart $(2008)^{13}$ showed that among several nucleic acid markers for the diagnosis of leprosy, three had greater sensitivity and specificity (RLEP, Ag 85B, and 16S rRNA). Later, Martinez et al. (2011) ${ }^{18}$ demonstrated that the quantitative real-time PCR assay (qPCR) for the RLEP sequence could be used to improve the detection of infection in MB patients, due to its high sensitivity (100\%) and specificity (84.6\%). The authors concluded that qPCR positivity may indicate the presence of bacilli or subclinical infections, which does not mean that the condition will progress to disease. However, the RLEP is highly conserved in bacteria of the same genus, which raises some questions about its usage as a diagnostic marker.

A study by Martinez et al. (2011) $)^{18}$ compared the sensitivity and specificity of qPCR in the amplification of the sodA, 16S rRNA, RLEP, and Ag 85B genes for the differential diagnosis of leprosy, confirming that the RLEP sequence confers greater sensitivity to the technique. However, the RLEP sequence was amplified in four patients with other skin diseases. In comparison, the amplification of the 16S rRNA gene, although less sensitive, was specific for M. leprae. In a previous study, Martinez et al. (2009) $)^{20}$ confirmed the specificity of the M. leprae $16 \mathrm{~S}$ rRNA qPCR primers by testing them with 9 other Mycobacterium species. Gama et al. (2018) ${ }^{21}$, using qPCR to detect $M$. leprae DNA in earlobe dermal shavings and blood samples from leprosy cases and household contacts living in an endemic area, identified the infection in $23.89 \%$ of clinically asymptomatic contacts. These data corroborate the high potential of this tool for the early diagnosis of leprosy.

\section{SEROLOGICAL ASSAYS}

Serological tests are aimed at detecting specific antibodies against $M$. leprae that indicate infection. These tests can be useful in monitoring the effectiveness of therapy, determining the prevalence of the disease, and assessing the distribution of infection in a particular community ${ }^{22,23}$. The elucidation of the chemical structure of Phenolic glycolipid 1 (PGL-I), a specific antigen of M. leprae, in 1981 made it possible to create serological tests for diagnosis ${ }^{24}$. Studies involving PGL-I mainly use the ELISA technique ${ }^{25}$. The low cost and quantitative results have made anti-PGL-I serology a widely used method. In addition to ELISA, rapid anti-PGL-I assays have been developed, such as the Dipstick ${ }^{22}$ and lateral flow immunochromatographic assays including the ML Flow ${ }^{26}$ and ML ICA. These are more straightforward tests than ELISA, as they do not require the use of laboratory equipment or a specialized laboratory technician, and provide reproducible results ${ }^{27}$. AntiPGL-I serology can identify patients for early monitoring and treatment and can reduce neural damage and disability ${ }^{28}$.

After the M. leprae genome was published ${ }^{29}$, new bacillus-specific proteins or peptides with potential applicability in the diagnosis of leprosy were identified ${ }^{30-37}$. Serology results using recombinant M. leprae proteins reflect the immune spectrum of the disease: high levels of antibodies at the lepromatous pole and lower levels of antibodies at the tuberculoid pole ${ }^{32}$. In a study that evaluated the humoral and cellular immune response to $33 \mathrm{M}$. leprae recombinant proteins, three (ML0405, ML2055, and ML2331) were identified as immunogenically capable of inducing a specific cellular immune response in $\mathrm{PB}$ patients and humoral response by production of IgG in MB patients. From these advances, Leprosy IDRI Diagnostic-1 (LID-1) was obtained by fusing the ML0405 and ML2331 genes to produce a single chimeric protein with better sensitivity ${ }^{31,38}$.

Subsequently, the LID-1 and PGL-I epitopes were conjugated to form NDO-LID, ensuring the immunoreactivity of the two isolated proteins, indicating potential application in serological diagnosis, mainly 
in the early detection of cases ${ }^{39,40}$. According to Frade et al. (2017) ${ }^{41}$, the commercial rapid test NDO-LID (Orange Life, Rio de Janeiro, Brazil) was positive in $62.8 \%$ of patients clinically diagnosed with leprosy. However, it showed less specificity than the anti-PGL-I and anti-LID-1 ELISAs. Although this test can identify dominant responses to both the glycolipid (IgM anti-PGL-I) and protein (IgG anti-LID-1), the NDO-LID has the same limitation as other rapid diagnostic tests, highlighting the difficulty of using this test to monitor individuals in the early stages of the disease and/or PB. Regardless, the use of serological tests associated with clinical examination, can contribute to the early detection and treatment of leprosy. Serological tests perform better in the identification of MB patients, especially the BL and LL forms. Additionally, BL and LL patients produce high IgM titers against PGL-I, while TT patients have low levels of specific antibodies ${ }^{23}$.

\section{CONTACT SURVEILLANCE: IMPORTANCE OF MOLECULAR AND SEROLOGICAL TESTS}

Contact surveillance is done using a dermatoneurological exam. The aim of contact surveillance is to diagnose new cases among people who have prolonged close interactions with a newly diagnosed leprosy patient (called an index case). Contacts of leprosy cases have a higher risk of illness since they have a greater exposure to M. leprae than the general population ${ }^{42}$. Two groups of people are considered close contacts, those who reside or used to reside with the patient (household contacts) and those who interact or used to interact closely with the patient (social contacts) ${ }^{9}$.

The detection of $M$. leprae DNA has been carried out using several clinical samples, such as nasal swabs, urine, saliva, and skin biopsies ${ }^{43,44,45}$. In household contacts, the detection of $M$. leprae DNA by PCR of nasal swabs does not determine whether the contact will progress to active disease. However, PCR is a very specific test, and several specialists advise treatment of all PCR-positive contacts. The rates of DNA detection in nasal swabs from contacts vary from $1 \%$ to $10 \%$ depending on the clinical form of the index case. The positivity rates observed among healthy individuals raise questions about the feasibility of using PCR on nasal swab samples to predict the risk of developing the disease. Recently, studies have indicated that the risk of progressing to active disease increases if the contact is positive for blood PCR ${ }^{46,47}$.

Anti-PGL-I seropositivity and the hidden prevalence of leprosy among household contacts and school-aged children indicate the presence of active infection foci. The serological test can be used to identify school-age children with a higher risk of developing leprosy ${ }^{48}$. The high prevalence of PGL-I seropositivity among contacts of MB patients shows that subclinical infection might be common $^{49-51}$. The detection of antibodies against PGL-I identifying infected contacts without apparent clinical signs can be an auxiliary tool for leprosy control programs.

The reactivity of IgM and IgG antibodies against NDO-LID may allow the detection of infections at an early stage ${ }^{40}$. Additionally, household contacts with anti-PGL- ${ }^{31,52,54}$ and anti-NDO-LID ${ }^{39,53}$ seropositivity have a higher risk of developing leprosy ${ }^{31,39,52-54}$. The successive analysis of antibody reactivity can be useful, since the increase in anti-PGL-I and anti-LID-1 titers could identify household contacts that require further monitoring or be an indicator for conducting a clinical examination ${ }^{13,37,44}$.
Household contacts, in addition to having a subclinical infection, may also be actively involved in the spread of $M$. leprae to susceptible individuals in endemic regions, a worrying factor, since they may contribute to the leprosy transmission chain ${ }^{44}$.

In areas of greater endemicity, serological and molecular tests have been carried out and analyzed separately. However, Gama et al. (2019) $)^{55}$ proposed the integration of these methods to assist in the diagnosis and monitoring of household contacts using the Random Forest algorithm for data analysis. This is a robust multivariate analysis, able to build classification trees with minimal error rates, which is favorable for the diagnosis of diseases such as leprosy ${ }^{56,57}$.

Gama et al. (2019) $)^{55}$, used the classification model "Sick $\times$ Healthy" in the Random Forest analysis based on serological, molecular, and bacilloscopic data, to evaluate the prediction of infection in clinically diagnosed cases and household contacts, accompanying them for five years. This model, Random Forest, highlighted the possibility of early diagnosis of MB (90.5\%) and especially PB (70.6\%) cases, while separately evaluated tests did not reach the same high rate of diagnostic correctness.

\section{DISCUSSION \\ PERSPECTIVES FOR NEW LEPROSY DIAGNOSTIC TOOLS}

Early detection of leprosy is a strategy to interrupt the transmission of M. leprae and to prevent the occurrence of physical disability, a serious consequence. However, the diagnosis is still essentially defined by clinical examination. Slit skin smear and histopathology examinations are used to aid the clinical diagnosis and are useful in spectral and treatment categorization ${ }^{58}$.

A study carried out in a hyperendemic area of Brazil indicated that the anti-LID-1 assay has a sensitivity of $89 \%$ and a specificity of $42 \%$ for the diagnosis of leprosy. The low specificity is probably related to the presence of a large number of asymptomatic individuals infected with Mycobacterium ${ }^{59}$. Conversely, NDO-LID has a specificity of $85.89 \%$ and a sensitivity of $90.6 \%$ for MB and $27 \%$ for $\mathrm{PB}^{53}$. In that study, the authors correlated the ELISA results with the bacteriological index and the Ridley-Jopling classification since the lepromatous pole patients had higher responses. In contrast, in those of the tuberculoid pole, the antibody levels were lower. Other authors confirmed these results ${ }^{60,61}$. Additionally, the cases with high bacilloscopy index (BI) have high titers of anti-PGL-1 IgM ${ }^{41,61,62}$, anti-LID-1 $\operatorname{IgG}^{60}$, and anti-NDO-LID IgM and $\operatorname{IgG}^{40,53}$.

The detection of anti-PGL-I IgM contributes to the correct classification of leprosy cases ${ }^{27,62-64}$ and helps to differentiate between PB and MB cases $^{27,39,40,45,61,65-67}$. The analysis of IgG reactivity against LID-1 is also able to assist the diagnosis and operational classification of MB leprosy ${ }^{38,40,60,68}$, and IgM and IgG against NDO-LID allow for the rapid and consistent detection of MB leprosy as well as for the monitoring of these $\operatorname{cases}^{39,40}$.

The reactivity to LID-1 allows the diagnosis of leprosy 6 to 8 months before the clinical diagnosis of the disease. Thus, screening for anti-LID-1 antibodies, either in the population or in groups at risk, can significantly accelerate the treatment of leprosy cases and reduce transmission rates by decreasing the number of individuals who are discharging bacterial load ${ }^{31}$. 
It is important to note that serological tests already help determine the most appropriate type of multidrug therapy (MDT) ${ }^{61,62,69,70}$ and contribute to the reduction of possible nerve damage and the evolution of physical disabilities ${ }^{61}$. Additionally, they can help with treatment-related decision-making when smear microscopy is not available, as there is good agreement between serology and $\mathrm{BI}^{66,69,70,71,72}$.

Furthermore, the high sensitivity of qPCR to sputum smear microscopy makes this technique extremely important in clinical support for diagnosis ${ }^{12,13,20}$.

Knowing that leprosy is a disease with a long incubation period and that the symptoms are difficult to perceive in the initial stage of the infection, highlights that the monitoring of contacts with positive qPCR results is extremely important. About $6 \%$ to $8 \%$ of household contacts develop clinical symptoms of leprosy within two years of the diagnosis of the index case ${ }^{73}$.

Another important factor is the level of exposure of household contacts to the bacillus. Virchowian (VV) index cases transmit $M$. leprae from the nasal mucosa and lesions before starting treatment with polychemotherapy. Therefore, their household contacts are exposed to a higher bacillary burden. Individuals who live with PB index cases have a lower risk of developing leprosy due to the low potential for transmissibility ${ }^{74}$. Moreover, Banerjee et al. $(2010)^{75}$ showed that $10.9 \%$ of VV case contacts had positive PCR results and $1.8 \%$ of these individuals developed leprosy over 2 years.

On the other hand, an explanation for the negative qPCR results in some patients, especially paucibacillary patients, is the possibility of inhibited amplification of $M$. leprae DNA due to the high concentration of human genomic DNA in the samples, as described by Martinez et al. $(2006)^{43}$.

A way of improving laboratory diagnostic capacity was assessed by the integrated analysis of serological and molecular tests using the Random Forest algorithm, which showed greater sensitivity and specificity in identifying MB and PB cases as well as subclinical infections in household contacts ${ }^{55}$.

Bacillus calmette guerin (BCG) vaccination promotes a certain rate of protection against the development of leprosy, in the general population and in household contacts, especially when applied in two doses ${ }^{76}$. Sales et al. (2011) $)^{77}$ observed a protection rate of 56\% in contacts who received the BCG vaccine. Despite this protection, some contacts developed leprosy, of which $89 \%$ presented the PB form, which indicates the protective effect of the vaccine against the development of the VV form.

In addition to BCG vaccination, chemoprophylaxis of contacts has also been evaluated as a strategy for leprosy control. A study by Moet et al. $(2008)^{76}$ in Bangladesh indicated that a single chemoprophylactic dose of rifampicin administered to contacts was effective in preventing the development of leprosy in 57\% of treated individuals. This protective effect of chemoprophylaxis was observed for a two-year follow-up period.

Fischer et al. (2011) ${ }^{78}$ used a microsimulation model to compare results from different hypothetical leprosy intervention programs, showing that the strategy of early diagnosis of subclinical infection associated with treatment achieves a higher cure rate compared to the application of chemoprophylaxis alone.

\section{CONCLUSION}

Molecular and serological assays are very promising for the diagnosis of leprosy. Although many studies have been carried out in isolation, the integrated assessment of the methods could increase the sensitivity and specificity, contributing to early diagnosis or monitoring of household contacts, thus promoting greater control of the disease.

The evaluation of protocols and proposal of an integrated diagnostic model of molecular, serological, and clinical techniques for large-scale application is suggested. Additionally, an economic/ financial study is essential to enable its implementation in health services. Therefore, we propose the development of prototypes of low-cost molecular and serological tests to implement in central laboratories, such as the Central Public Health Laboratories (LACEN) in Brazil. Clinical data must be associated with laboratory results to validate an integrated analysis model using software or an application to predict leprosy diagnosis.

\section{ACKNOWLEDGMENTS}

We offer our deepest thanks to the institutions that provided technical support for the development and implementation of this study Universidade Vale do Rio Doce and Universidade Federal de Juiz de Fora.

\section{FINANCIAL SUPPORT}

Universidade Vale do Rio Doce.

\section{AUTHORS' CONTRIBUTION}

RSG: Conception and design or analysis and interpretation of data; Writing of the article or relevant critical review of the intellectual content; Final approval of the version to be published; responsible for all aspects of the work in ensuring the accuracy and integrity of any part of the work; LAL: Conception and design or analysis and interpretation of data; Writing of the article or relevant critical review of the intellectual content; Final approval of the version to be published; LTC: Conception and design or analysis and interpretation of data; Writing of the article or relevant critical review of intellectual contente; LAOF: Writing of the article or relevant critical review of the intellectual content; Final approval of the version to be published.

\section{CONFLICTS OF INTEREST}

The authors declare that they have no conflict of interest.

\section{REFERENCES:}

1. Scollard DM, Adams LB, Gillis TP, Kragenbuhl JL, Truman RW, Willians DL. The continuing challenges of leprosy. Clin Microbiol Rev. 2006;19(2):338-81.

2. Ministério da Saúde. Secretaria de Vigilância em Saúde - Boletim Epidemiológico. 2020; Número Especial. Jan. 2020.52p.

3. World Health Organization (WHO). Global leprosy update, 2018: moving towards a leproy free world. Weekly Epidemiological Record, Genebra, n. 94, p. 389-412, 30/08/2019.

4. Fine PE, Ponnighaus JM, Burgess P, Clarkson JA, Draper CC. Seroepidemiological studies of leprosy in northern Malawi based on na enzyme-linked immunosorbent assay using synthetic glycoconjugate antigen. Int J Lepr Other Mycobact Dis. 1988;56(2):243-54. 
5. Mira MT. Genetic host resistance and susceptibility to leprosy. Microbes Infect. 2006;8(4):1124-31.

6. Worobec SM. Current approaches and future directions in the treatment of leprosy. Res Rep Trop Med. 2012;3:79-91.

7. Ministério da Saúde. Secretaria de Vigilância em Saúde. Departamento de Vigilância Epidemiológica. Guia de procedimentos técnicos: baciloscopia em hanseníase. Brasília: Editora do Ministério da Saúde; 2010. 51p.

8. Baptista IMFD, Sartori BCS, Trino LM. Guia de conduta para realização do exame baciloscópico. Hansen Int. 2006; 31(2):39-41.

9. Ministério da Saúde. Secretaria de Vigilância em Saúde. Departamento de Vigilância das Doenças. Diretrizes para vigilância, atenção e eliminação da Hanseníase como problema de saúde pública: manual técnico-operacional. Brasília: Ministério da Saúde; 2016. 60p.

10. Ridley DS, Jopling WH. Classification of leprosy according to immunity: a Five group system. Int J Lepr. 1966;34:255-73.

11. Bennett, BH, Parker, DL., Robson M. Leprosy: steps along the journey of eradication. Public Health Rep. 2008;123(2):198-205.

12. Kang TJ, Kim SK, Lee SB, Chae GT, Kim JP. Comparison of two different PCR amplification products (the 18-kDa protein gene vs. RLEP repetitive sequence) in diagnosis of Mycobacterium Leprae. Clin Exp Dermatol. 2003;28:420-4

13. Goulart IMB, Goulart LR. Leprosy: diagnostic and control challenges for a worldwide disease. Arch Dermatol Res. 2008;300(6):269-90.

14. Kampirapap K, Singtham N, Klatser PR, Wiriyawipart S. DNA amplification for detection of leprosy and assessment of efficacy of leprosy chemotherapy. Int J Lepr Other Mycobact Dis.1998;66:16-21.

15. Scollard DM, Gillis TP, Williams DL. Polymerase chain reaction assay for the detection and identification of Mycobacterium Leprae in patients in the United States. Am J Clin Pathol. 1998;109(5):642-6.

16. Plikaytis BB, Gelber RH, Shinnick TM. Rapid and sensitive detection of Mycobacterium Leprae using a nested-primer gene amplification assay. J Clin Microbiol. 1990;8(9):1913-7.

17. Woods, SA, Cole ST. A rapid method for detection of potentially viable Mycobacterium Leprae in human biopsies: a novel amplification of PCR. FEMS Microbiol Lett. 1989;65:305-9.

18. Martinez AN, Ribeiro-Alves M, Sarno EN, Moraes MO. Evaluation of qPCR-Based Assays for Leprosy Diagnosis Directly in Clinical Specimens. PLoS Negl Trop Dis. 2011;5(10):1354.

19. Turankar RP, Pandey S, Lavania M, Singh I, Nigam A, Darlong J, Darlong F, Sengupta U. Comparative evaluation of PCR amplification of RLEP, 16S rRNA, rpoT and Sod A gene targets for detection of M. leprae DNA from clinical and environmental samples of Mycobacterium Leprae viability by use of Real-Time PCR. Int J Mycobacteriol. 2009;47(7):2124-30.

20. Martinez AN, Lahiri R, Pittman TL, Scollard D, Truman R, Moraes $\mathrm{MO}$, et al. Molecular detection of Mycobacterium Leprae viability by use of Real-Time PCR. J Clin Microbiol. 2009; 47(7):2124-30.

21. Gama RS, Gomides TAR, Gama CFM, Moreira SJM, de Neves Manta FS, de Oliveira LBP, Marçal PHF, Sarno EN, Moraes MO, Garcia RMG, de Oliveira Fraga LA. High frequency of M. leprae DNA detection in asymptomatic household contacts. BMC Infectious Dis. 2018;18:153.

22. Bührer-Sékula S, Cunha MG, Foss NT, Oskam L, Faber WR, Klatser PR. A simple dipstick assay for the detection of antibodies to phenolic glycolipid-I of Mycobacterium leprae. Am J Trop Med Hyg. 1998;58(2)133-6

23. Moura RS, Calado KL, Oliveira MLW, Buhrer-Sékula S. Sorologia da hanseníase utilizando PGL-I: revisão sistemática. Rev Soc Bras Med Trop. 2008;41:11-8.
24. Hunter SW, Brennan PJ. A novel phenolic glycolipid from Mycobacterium Leprae possibly involved in immunogenicity and pathogenicity. J Bacteriol. 1981; 147(3):728-35.

25. Brett SJ, Payne SN, Gigg J, Burgess P, Gigg R. Use of synthetic glycoconjugates containing the Mycobacterium Leprae specific and immunodominant epitope of phenolic glycolipid I in the serology of leprosy. Clin Exp Immunol. 1986;64(3): 476-83.

26. Bührer-Sékula S, Smits HL, Gussenhoven GC, van Leeuwen J, Amador S, Fujiwara T, et al. Simple and fast lateral flow test for classification of leprosy patients and identification of contacts with high risk of developing leprosy. J Clin Microbiol. 2003;41(5):1991-5.

27. Stefani MM, Grassi AB, Sampaio LH, Sousa AL, Costa MB, Scheelbeek $\mathrm{P}$, et al. Comparison of two rapid tests for anti-phenolic glycolipid-I serology in Brazil and Nepal. Mem Inst Oswaldo Cruz. 2012;107:124-31.

28. Roche PW, Theuvenet WJ, Britton WJ. Risk factors for type-1 reactions in borderline leprosy patients. Lancet; 1991;338(8768):654-7.

29. Cole ST, Eiglmeier K, Parkhill J, James KD, Thomson NR, Wheeler PR, et al. Massive gene decay in the leprosy bacillus. Nature. 2001;409(6823):1007-11.

30. Aráoz R, Honoré N, Cho S, Kim JP, Cho SN, Monot M, et al. Antigen discovery: a postgenomic approach to leprosy diagnosis. Infect Immun. 2006;74(1):175-82.

31. Duthie MS, Goto W, Ireton GC, Reece ST, Cardoso LP, Martelli CM, et al. Use of protein antigens for early serological diagnosis of leprosy. Clin Vaccine Immunol. 2007;14(11):1400-08.

32. Stefani MMA. Challenges in the post genomic era for the development of tests for leprosy diagnosis. Rev Soc Bras Med Trop. 2008;41:89-94.

33. Geluk A, Spencer JS, Bobosha K, Pessolani MC, Pereira GM, Banu S, et al. From genome-based in silico predictions to ex vivo verification of leprosy diagnosis. Clin Vaccine Immunol. 2009;16(3):352-9.

34. Sampaio LH, Stefani MM, Oliveira RM, Sousa AL, Ireton GC, Reed $\mathrm{SG}$, et al. Immunologically reactive M. leprae antigens with relevance to diagnosis and vaccine development. BMC Infect Dis. 2011;11:26.

35. Hungria EM, Oliveira RM, Souza AL, Costa MB, Souza VN, Silva EA, et al. Seroreactivity to new Mycobacterium Leprae protein antigens in different leprosy-endemic regions in Brazil. Mem Inst Oswaldo Cruz. 2012;107:104-11.

36. Spencer JS, Duthie MS, Geluk A, Balagon MF, Kim HJ, Wheat WH, et al. Identification of serological biomarkers of infection, disease progression and treatment efficacy for leprosy. Mem Inst Oswaldo Cruz. 2012;107:79-89.

37. Marçal PHF, Fraga LAO, Mattos AMM, Menegati L, Coelho ACO, Pinheiro RO, et al. Utility of immunoglobulin isotypes against LID1 and NDO-LID for, particularly IgG1, confirming the diagnosis of multibacillary leprosy. Mem Inst Oswaldo Cruz. 2018;113(5):e170467.

38. Duthie MS, Goto W, Ireton GC, Reece ST, Sampaio LH, Grassi AB, et al. Antigen-specific T-cell responses of leprosy patients. Clin Vaccine Immunol. 2008;15(11):1659-65.

39. Cardoso PVL, Dias RF, Freitas AA, Hungria EM, Oliveira RM, Collovati M. Development of a quantitative rapid diagnostic test for multibacillary leprosy using smart phone technology. BMC Infect Dis. 2013;13(497).

40. Duthie MS, Raychaudhuri R, Tutterrow YL, Misquith A, Bowman J, Casey A, et al. A rapid ELISA for the diagnosis of MB leprosy based on complementary detection of antibodies against a novel proteinglycolipid conjugate. Diagn Microbiol Infect Dis. 2014;79(2):233-9.

41. Frade MA, de Paula NA, Gomes CM, Vernal S, Bernardes Filho F, Lugão HB, et al. Unexpectedly high leprosy seroprevalence detected 
using a random surveillance strategy in midwestern Brazil: A comparison of ELISA and a rapid diagnostic test. PLoS Negl Trop Dis. 2017;11:e0005375.

42. Amorim FM, Nobre ML, Ferreira LC, Nascimento LS, Miranda AM, Monteiro GR, et al. Identifying leprosy and those at risk of developing leprosy by detection of antibodies against LID-1 and LID-NDO. PLOS Negl Trop Dis. 2016;10(9): e0004934.

43. Martinez AN, Britto CF, Nery JA, Sampaio EP, Jardim MR, Sarno EN, Moraes MO. Evaluation of real-time and conventional PCR targeting complex 85 genes for detection of Mycobacterium leprae DNA in skin biopsy samples from patients diagnosed with leprosy. J Clin Microbiol. 2006 Sep;44(9):3154-9.

44. Araújo S, Lobato J, Reis Ede M, Souza DO, Gonçalves MA, Costa $\mathrm{AV}$, et al. Unveiling healthy carriers and subclinical infections among household contacts of leprosy patients who play potential roles in the disease chain of transmission. Mem Inst Oswaldo Cruz. 2012;107:55-9.

45. Caleffi KR, Hirata RDC, Hirata MH, Caleffi ER, Siqueira VLD, Cardoso $\mathrm{RF}$. Use of the polymerase chain reaction to detect Mycobacterium Leprae in urine. Braz J Med Biol Res. 2012;45(2):153-7.

46. Hacker MA, Sales AM, Illarramendi X, Nery JA, Duppre NC, Bastos FI, et al. A profile of patients treated at a national leprosy outpatient referral clinic in Rio de Janeiro, Brazil, 1986-2007. Rev Panam Salud Publica. 2012;31:485-91.

47. Reis EM, Araujo S, Lobato J, Neves AF, Costa AV, Gonçalves MA, et al. Mycobacterium leprae DNA in peripheral blood may indicate a bacilli migration route and high risk for leprosy onset. Clin Microbiol Infect. 2013;20(5):447-52.

48. Barreto JG, Guimarães LS, Leão MR, Ferreira DV, Lima RA, Salgado CG. Anti-PGL-I seroepidemiology in leprosy cases: household contacts and school children from a hyperendemic municipality of the Brazilian Amazon. Lepr Rev. 2011;82: 358-70.

49. Desforges S, Bobin P, Brethes B, Huerre M, Moreau JP, Bach MA. Specific anti-M leprae PGL-I antibodies and mitsuda reaction in the management of household contacts in new caledonia. Int J Lepr Other Mycobact Dis. 1989;57(4):794-800.

50. Menzel S, Harboe M, Bergsvik H, Brennan PJ. Antibodies to a synthetic analog of phenolic glycolipid-I of Mycobacterium Leprae in healthy household contacts of patients with leprosy. Int J Lepr other Mycobact Dis. 1987;55(4):25-617.

51. Saad MH, Medeiros MA, Gallo ME, Gontijo PP, Fonseca LS. IgM immunoglobulins reacting with the phenolic glycolipid-1 antigen from Mycobacterium Leprae in sera of leprosy patients and their contacts. Mem Inst Oswaldo Cruz. 1990;85(2):191-194.

52. Düppre NC, Camacho LA, Sales AM, Illarramendi X, Nery JA, Sampaio EP, et al. Impact of PGL-I Seropositivity on the protective effect of BCG vaccination among leprosy contacts: A Cohort Study. PLoS Negl Trop Dis. 2012;6(6):e1711.

53. Duthie MS, Balagon MF, Maghanoy A, Orcullo FM, Cang M, Dias RF. Rapid quantitative serological test for detection of infection with Mycobacterium Leprae, the causative agent of leprosy. J Clin Microbiol. 2014;52(2):613-9.

54. Douglas JT, Cellona RV, Fajardo TT Jr, Abalos RM, Balagon MV, Klatser PR. Prospective study of serological conversion as a risk factor for development of leprosy among household contacts. Clin Diagn Lab Immunol. 2004;11(5):897-900.

55. Gama RS, Souza MLM, Sarno EN, Moraes MO, Gonçalves A, Stefani MMA, et al. A novel integrated molecular and serological analysis method to predict new cases of leprosy amongst household contacts. PLoS Negl Trop Dis. 2019;13(6): e0007400.
56. Breiman L. Random Forests. Machine Learning. 2001;45:5-32.

57. Baker PT, Caudill S, HHodge KA, Talukder D, Capano C, Cornish NJ. Multivariate Classification with Random Forests for gravitational wave searches of black hole binary coalescence. Phys Rev. 2014;91(6).

58. Worobec, S. M. Current approaches and future directions in the treatment of leprosy. Res Rep Trop Med. 2012;3:79-91.

59. de Souza MM, Netto EM, Nakatani M, Duthie MS. Utility of recombinant proteins LID-1 and PADL in screening for Mycobacterium Leprae infection and leprosy. Trans R Soc Trop Med Hyg. 2014;108(8):495-501.

60. Duthie MS, Hay MN, Rada EM, Convit J, Ito L, Oyafuso LK, et al. Specific IgG antibody responses may be used to monitor leprosy treatment efficacy and as recurrence prognostic markers. Eur J Clin Microbiol Infect Dis. 2011;30(10): 1257-65.

61. Lobato J, Costa MP, Reis Ede M, Gonçalves MA, Spencer JS, Brennan $\mathrm{PJ}$, et al. Comparison of three immunological tests for leprosy diagnosis and detection of subclinical infection. Lepr Rev. 2011;82(4):389-401.

62. Grossi MAF, Leboeuf MAA, Andrade RC, Buhrer-Sékula S, Antunes CMF. Risk Factors for ML Flow Seropositivity in leprosy patients. Rev Soc Bras Med Trop. 2008;41:39-44.

63. Brito MF, Ximenes RA, Gallo ME, Bührer-Sékula S. Association between leprosy reactions after treatment and bacterial load evaluated using anti PGL-I serology and Bacilloscopy. Rev Soc Bras Med Trop. 2008;41:67-72.

64. Bührer-Sékula S, Visschedijk J, Grossi MA, Dhakal KP, Namadi AU, Klatser PR, et al. The ML flow test as a point of care test for leprosy control programmes: potential effects on classification of leprosy patients. Lepr Rev. 2007;78(1):70-79.

65. Ferreira IN, Ferreira IL, Evangelista MS, Alvarez RR. The use of ML Flow test in school children diagnosed with leprosy in the district of Paracatu, Minas Gerais. Rev Soc Bras Med Trop. 2008;41:77-80.

66. Da Silva RC, Lyon S, Lyon AC, Grossi MA, Lyon SH, Bührer-Sékula $\mathrm{S}$, et al. Correlation between ELISA and ML Flow assays applied to 60 Brazilian patients affected by leprosy. Trans R Soc Trop Med Hyg. 2010;104(8):546-50.

67. Teixeira AC, Cruvinel DL, Roma FR, Luppino LF, Resende LH, Sousa T, et al. Evaluation of the agrément between clinical and laboratorial exams in the diagnosis of leprosy. Rev Soc Bras Med Trop. 2008;41:4855.

68. Rada E, Duthie MS, Reed SG, Aranzazu N, Convit J. Serologic follow-up of IgG responses against recombinant mycobacterial proteins ML0405, ML2331 and LID-1 in a leprosy hyperendemic area in Venezuela. Mem Inst Oswaldo Cruz. 2012;107:90-4.

69. Contin LA, Alves CJ, Fogagnolo L, Nassif PW, Barreto JA, Lauris JR, et al. Use of the ML-Flow test as a tool in classifying and treating leprosy. An Bras Dermatol. 2011;86(1):91-5.

70. Lyon S, Castorina SR, Lyon AC, Grossi MA, Lyon SH, Azevedo ML, et al. Association of the ML Flow serologic test to slit skin smear. Rev Soc Bras Med Trop. 2008;41:23-6.

71. Bührer-Sékula S, Illarramendi X, Teles RB, Penna ML, Nery JA, Sales $\mathrm{AM}$, et al. The additional benefit of the ML flow test to classify leprosy patients. Acta Trop. 2009;111(2):172-6.

72. Limeira OM, Gomes CM, Morais OO, Cesetti MV, Alvarez RR. Active search for leprosy cases in midwestern Brazil: A serological evaluation of asymptomatic household contacts efore and after prophylaxis with bacillus calmette-guérin. Rev Inst Med Trop São Paulo. 2013;55(3): 173-7.

73. Ottenhoff TH. Immunology of leprosy: lessons from and for leprosy. Int J Lepr Other Mycobact Dis. 1994;62(1):108-21. 
74. Job CK, Jayakumar J, Kearney M, Gillis TP. Transmission of leprosy: a study of skin and nasal secretions of household contacts of leprosy patients using PCR. Am J Trop Med Hyg. 2008;78:518-21.

75. Banerjee S, Sarkar K, Gupta S, Mahapatra PS, Gupta S, Guha S, et al. Multiplex PCR technique could be an alternative approach for early detection of leprosy among close contacts--a pilot study from India. BMC infectious diseases. 2010; 10: 252.

76. Moet FJ, Pahan D, Schuring RP, Oskam L, Richardus JH. Physical distance, genetic relationship, age, and leprosy classification are independent risk factors for leprosy in contacts of patients with leprosy. J Infect Dis. 2006;193:346-53.

77. Sales AM, Ponce de Leon A, Düppre NC, Hacker MA, Nery JA, Sarno EN, Penna ML. Leprosy among patient contacts: a multilevel study of risk factors. PLoS Negl Trop Dis. 2011 Mar 15;5(3):e1013.

78. Fischer EA, de Vlas SJ, Habbema JD, Richardus JH. The long-term effect of current and new interventions on the new case detection of leprosy: a modeling study. PLoS Negl Trop Dis. 2011 Sep;5(9):e1330. doi: 10.1371/journal.pntd.0001330. Epub 2011 Sep 20. 